\title{
KAJIAN RENCANA PENERAPAN RUANG HENTI KHUSUS SEPEDA MOTOR DI PERSIMPANGAN BERSINYAL (STUDI KASUS KOTA MALANG)
}

\section{A Study on The Implementation Plan of Exclusive Stopping Space (ESS) in The Traffic Light (A Case Study in Malang)}

\author{
Ayu Roesdyningtyas D. A. ${ }^{1}$, Achmad Wicaksono ${ }^{2}$, Ruslin Anwar ${ }^{3}$ \\ 1,2,3 Jurusan Teknik Sipil/Fakultas Teknik/Universitas Brawijaya \\ Jl. M. T. Haryono No 167, Malang 65145, Jawa Timur \\ E-mail: ayuanggraeny@yahoo.com
}

\begin{abstract}
The growth of vehicles nowadays is getting uncontrollably increased, especially motorcycles. Due to the condition, the aims of this study are to know the characteristics of motorcycle riders on the basis of their social economic and trip characteristics, to recognize the riders' perception on the existence of Exclusive Stopping Space, and to make proposal for the policy of providing Exclusive Stopping Space (ESS). The research method is using Logistic Regression, and Analytic Hierarchy Process (AHP). Characteristic of a rider, male sex (64\%), age 18-22 years $(27 \%)$, education sma / ma (57\%), income < Rp 1,000,000 (33 $\%)$, private work (43\%), self owned (86\%), and number of motorcycles 1 (57\%), came from a house (79\%), mean travel work (51\%), purpose of work site (51\%), mileage $5 \mathrm{~km}-10 \mathrm{~km}(25 \%)$, routine activities 6 times / week (45\%), and travel time 20 - 30 minutes (35\%).

Criteria choice of location for provision of Exclusive Stopping Space in Malang city,criteria aspect of safety $(35,188 \%)$, aspect of travel time (15,592 \%), aspect of comfort (13,397 \%), aspect of social economy (10,589\%), aspect of building cost (9,840 \%), aspects of technical (9,078\%), and aspect of environmental conservation $(6,316 \%)$.
\end{abstract}

Keywords : motorcycle rider characteristic, Exclusive Stopping Space, Logistic Regression, Analytic Hierarchy Process (AHP), conflic

\begin{abstract}
Abstrak
Pertumbuhan kendaraan bermotor dewasa ini kian bertambah hampir tak terkendali, khususnya sepeda motor. Oleh karena kondisi tersebut, tujuan kajian ini yaitu mengetahui karakteristik pengendara sepeda berdasarkan karakteristik sosial ekonomi dan karakteristik perjalanan, mengetahui hubungan persepsi pengendara sepeda motor terhadap penyediaan Ruang Henti Khusus, menyusun usulan untuk kebijakan penyediaan fasilitas Ruang Henti Khusus. Metode yang dipakai dalam kajian ini Logistic Regression, serta Metode Analytic Hierarchy Process (AHP). Karakteristik Pengendara sepeda motor di Kota Malang yaitu berjenis kelamin laki-laki (64\%), usia 18-22 tahun (27\%), pendidikan SMA/MA (57\%), penghasilan $<$ Rp 1.000 .000 (33\%), pekerjaan swasta (43\%), kepemilikan sepeda milik sendiri (86\%), dan jumlah sepeda motor $1(57 \%)$, berasal dari rumah $(79 \%)$, maksud perjalanan bekerja $(51 \%)$, tujuan lokasi kerja (51\%), jarak tempuh $5 \mathrm{~km}-10 \mathrm{~km}(25 \%)$, rutinitas kegiatan $6 \mathrm{kali} /$ minggu (45\%), dan waktu tempuh 20 - 30 menit (35\%). Bobot kriteia pemilihan lokasi penyediaan Ruang Henti Khusus di Kota Malang yaitu kriteria aspek keselamatan $(35,188 \%)$, aspek waktu tempuh $(15,592 \%)$, aspek kenyamanan $(13,397 \%)$, aspek sosial ekonomi $(10,589 \%)$, aspek biaya pembangunan $(9,840 \%)$, aspek teknis $(9,078 \%)$, dan aspek konservasi lingkungan $(6,316 \%)$.
\end{abstract}

Kata Kunci : karakteristik pengendara sepeda motor, Ruang Henti Khusus, Logistic Regression, Analytic Hierarchy Process (AHP), konflik

\section{PENDAHULUAN}

Pertumbuhan kendaraan bermotor dewasa ini kian bertambah hampir tak terkendali. Khususnya sepeda motor, hal ini dapat kita lihat dari data yang ada kota Malang (Malang dalam angka 2013). Pertumbuhan jumlah kendaraan sepeda motor dari tahun 2008 2012 berjumlah 175.000 unit. Dari data diatas jelas menunjukan jumlah sepeda motor sangat banyak dan mengakibatkan permasalahan transportasi tersendiri., khususnya di ruas - ruas jalan perkotaan. Persimpangan lalu lintas yang diatur dengan lampu lalu lintas juga tidak luput dari dampak keberadaan sepeda motor ini.

Sebagai kendaraan bermotor terkecil, sepeda motor merupakan kendaraan yang memiiki mobilitas dan manuver pergerakan yang tinggi. Ketika memasuki persimpangan, pengemudi sepeda motor cenderung memilih ruang sedekat mungkin ke garis henti (stop 
line) yang ada dipersimpangan daripada berada dibelakang kendaraan lain. Tidak jarang kendaraan - kendaraan ini menempatkan diri hingga melampui garis henti.

Pada saat sinyal hijau, kendaraan sepeda motor tersebut tampak berebut secepat mungkin dengan berbagai manuver pergerakan untuk keluar dari kelompok pada mulut persimpangan. Akibat manuver tersebut tidak jarang menimbulkan konflik lalu lintas yang diperkirakan memiliki pengaruh atau gangguan pergerakan terhadap kendaraan lainnya. Kondisi lalu lintas ini banyak ditemukan pada persimpangan persimpangan yang diatur lampu lalu lintas di kota Malang.

Oleh karena kondisi tersebut, maka diperlukan suatu penelitian yang mengarah pada kajian atau tinjauan pergerakan sepeda motor ketika keluar dari bentukan kelompok tak beraturan dari sepeda motor terhadap lalu lintas serta tinjauan penyediaan fasilitas khusus sepeda motor pada persimpangan.

Tujuan penelitian ini adalah untuk:

a. Mengetahui karakteristik dan persepsi pengendara sepeda motor terhadap rencana adanya Ruang Henti Khusus di mulut persimpangan bersinyal.

b. Mengetahui persepsi tentang penyediaan Ruang Henti Khusus dan mengetahui potensi persepsi penyediaan Ruang Henti Khusus dari Stakeholder.

\section{METODE PENELITIAN}

Metode pengumpulan data pada kajian ini menggunakan metode primer dan sekunder. Metode pengumpulan data sekunder dengan pengumpulan data dari instansi terkait yaitu peta jaringan jalan dan data populasi jumlah sepeda motor. Data primer yang diperlukan pada kajian ini yaitu dengan pengambilan data langsung di lapangan menggunakan angket/kuisioner. Wawancara dilakukan kepada pengendara sepeda motor, pemerintah, akademisi di lingkungan Kota Malang, data volume lalu lintas serta data konflik lalu lintas pada persimpangan yang menjadi lokasi studi.

Data yang telah diperoleh selanjutnya diolah dengan menggunakan analisa sebagai berikut :

\section{- Metode Analisa Logistic Regression}

Metode Analisa Logistic Regression digunakan untuk mengetahui persepsi pengendara sepeda motor terhadap penyediaan RHK dengan karakteristik sosial ekonomi dan karakteristik pergerakan. Persepsi tersebut diperoleh dari 400 responden pengendara sepeda motor di Kota Malang.

\section{- Metode Analytic Hierarchy Process (AHP)}

Metode Analytic Hierarchy Process $(A H P)$ dipakai mengetahui prioritas penyediaan RHK pada persimpangan di Kota Malang yang melibatkan stakeholder dan akademisi melalui wawancara. Prioritas penyediaan RHK ini diperoleh dari hasil wawancara kepada 23 responden stakeholder di pemerintahan Kota Malang dan akademisi dari Universitas Brawijaya.

\section{HASIL DAN PEMBAHASAN}

\section{Karakteristik Pengendara Sepeda Motor \\ - Karakteristik Sosial Ekonomi}

Karakteristik sosial ekonomi pengendara sepeda motor berdasarkan hasil survai dikelompokkan berdasarkan jenis kelamin, usia, pendidikan, penghasilan, pekerjaan, kepemilikan sepeda, jumlah sepeda yang dimiliki. Hasil survai pada responden pengendara sepeda motor sebagai berikut :

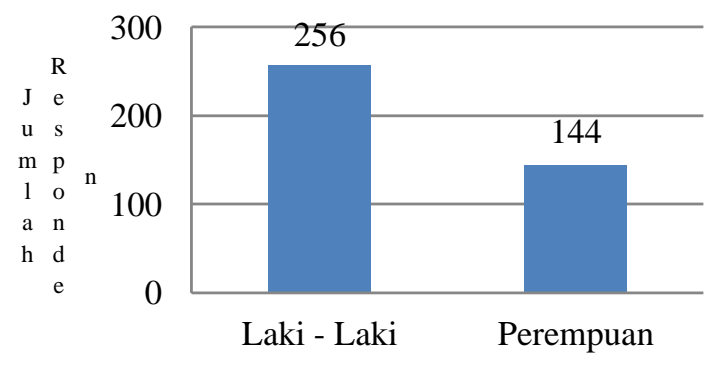

Gambar 1. Prosentase Jenis Kelamin

$$
\text { Pengendara Sepeda Motor }
$$

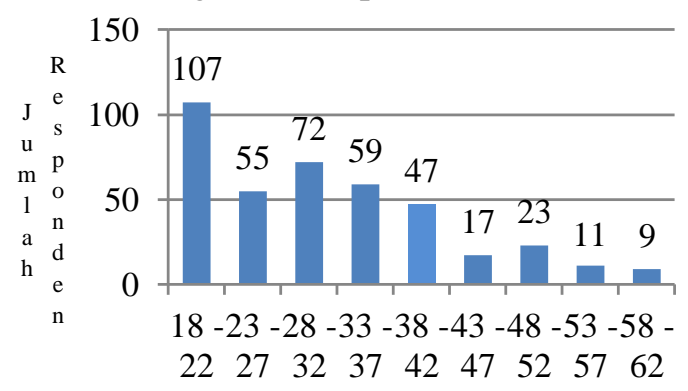

Gambar 2. Prosentase Usia Pengendara Sepeda Motor 


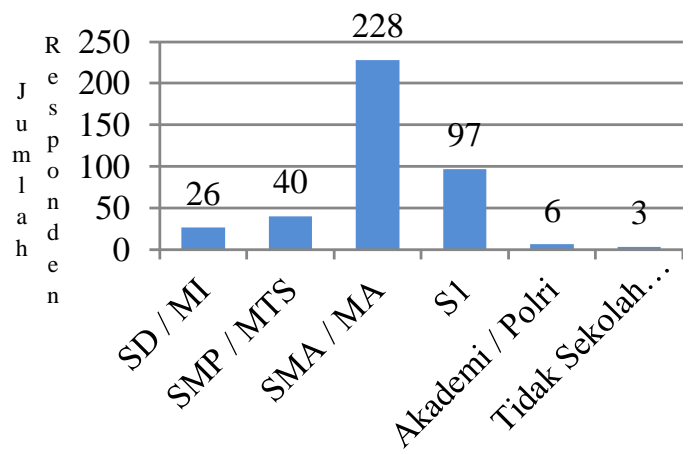

Gambar 3. Prosentase Pendidikan

Pengendara Sepeda Motor

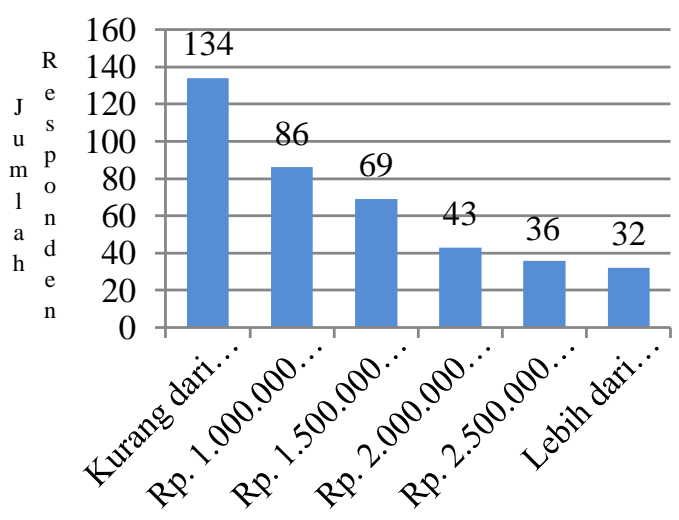

Gambar 4. Prosentase Penghasilan

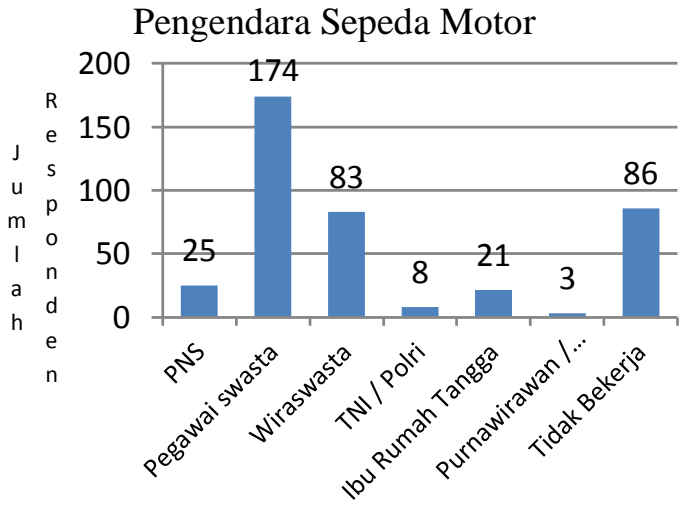

Gambar 5. Prosentase Pekerjaan Pengendara Sepeda Motor

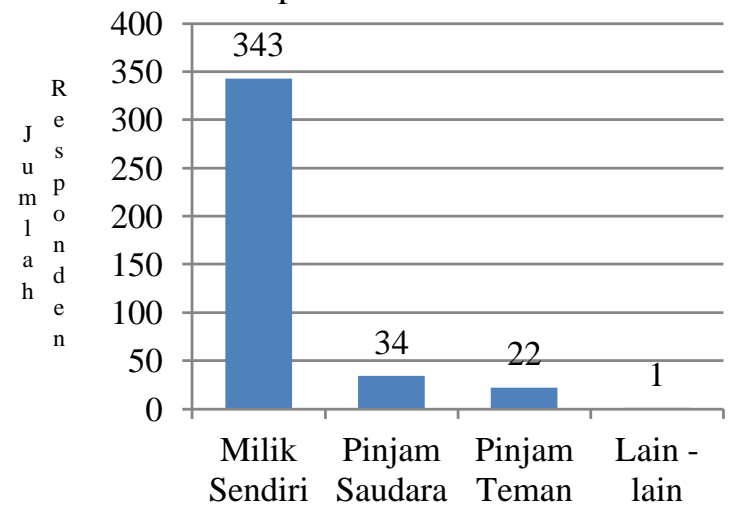

Gambar 6. Prosentase Kepemilikan

Pengendara Sepeda Motor

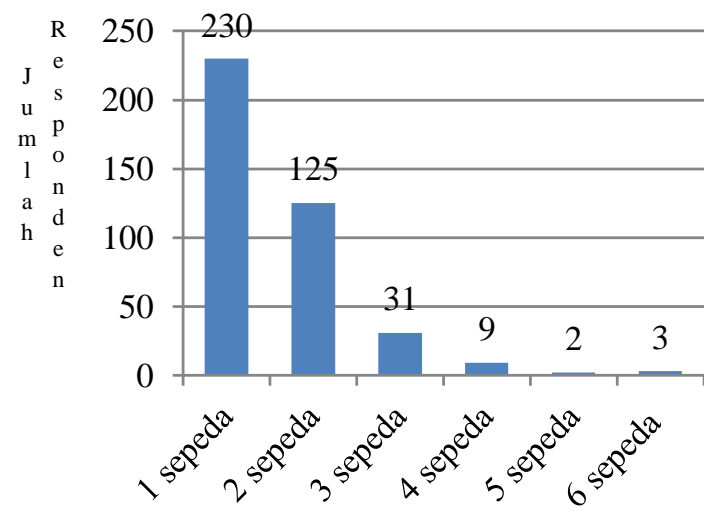

Gambar 7. Prosentase Jumlah Sepeda Motor Pengendara Sepeda Motor

\section{- Karakteristik Perjalanan}

Karakteristik perjalanan pengendara sepeda motor meliputi asal perjalanan, maksud perjalanan, tujuan perjalanan, jarak tempuh, rutinitas menggunakan sepeda, waktu tempuh. Hasil survai pada responden pengendara sepeda motor sebagai berikut :

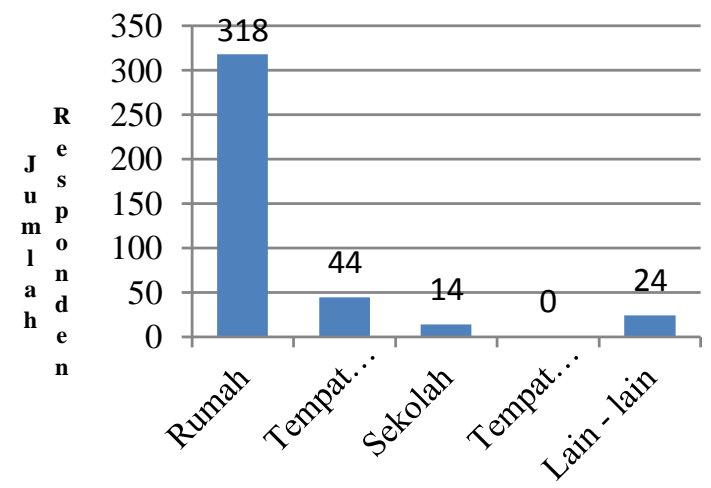

Gambar 8. Asal Perjalanan Pengendara Sepeda Motor

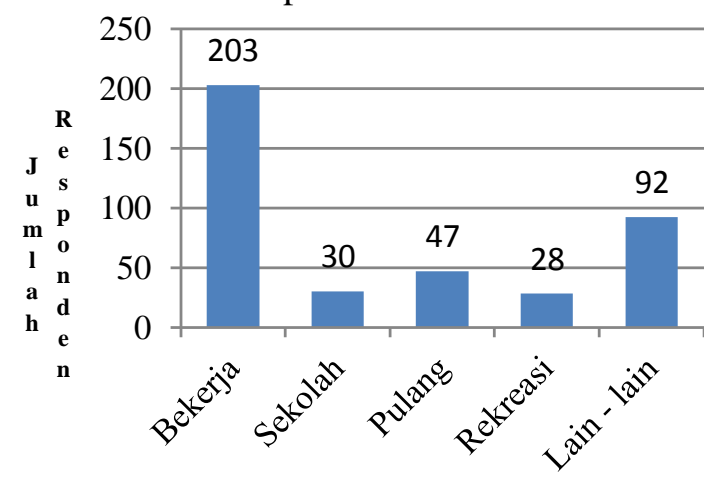

Gambar 9. Maksud Perjalanan Pengendara Sepeda Motor 


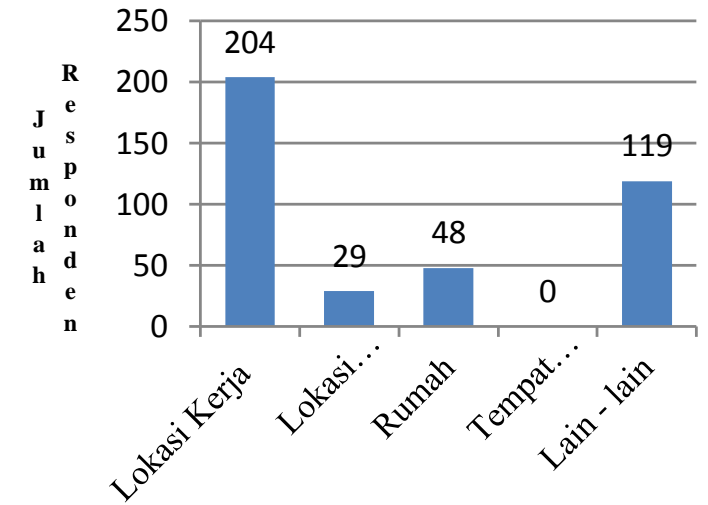

Gambar 10. Tujuan Perjalanan Pengendara Sepeda Motor

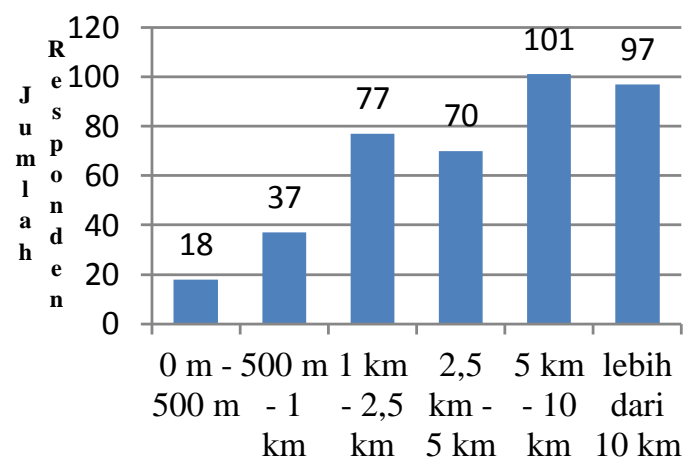

Gambar 11. Jarak Tempuh Pengendara Sepeda Motor

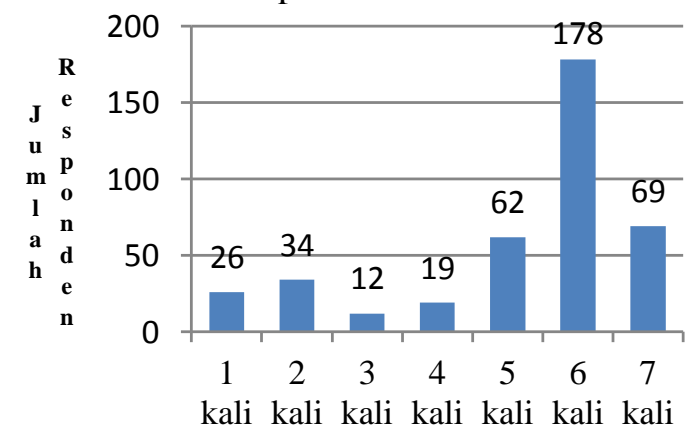

Gambar 12. Perjalanan/minggu Pengendara Sepeda Motor

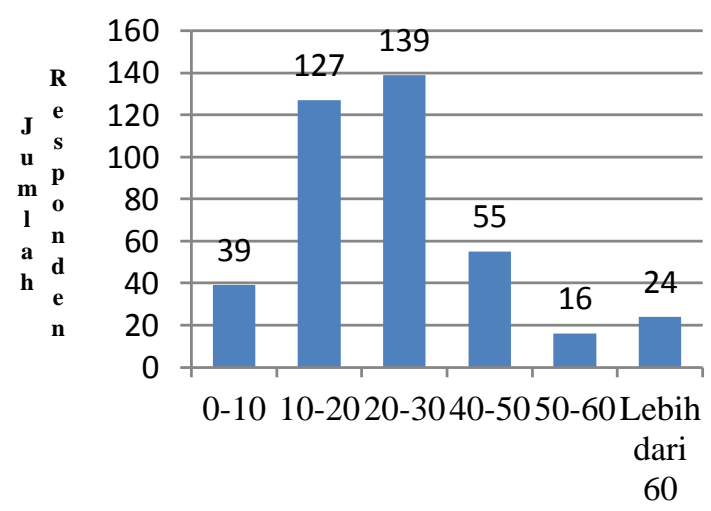

Gambar 13. Waktu Tempuh Pengendara Sepeda Motor
- Persepsi Pengendara Sepeda Motor terhadap Penyediaan Ruang Henti Khusus

Persepsi tentang penyediaan Ruang Henti Khusus sepeda motor ditanyakan kepada pengendara yaitu : persepsi tentang mau atau tidaknya menggunakan lajur pendekat dan Ruang Henti Khusus sepeda motor. Hasil survai pada responden pengendara sepeda motor sebagai berikut :

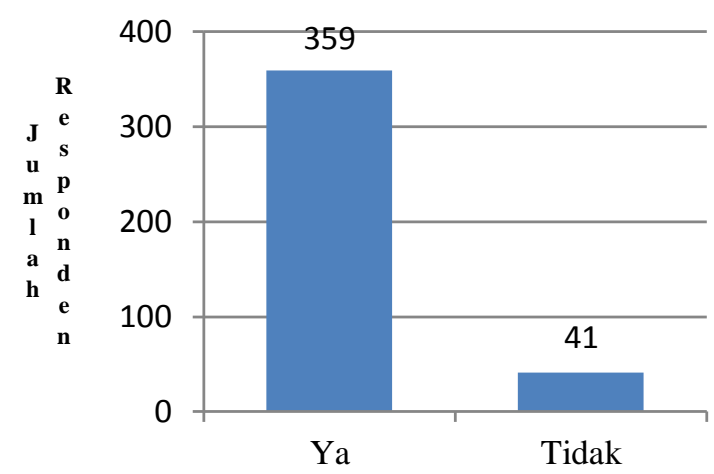

Gambar 14. Penggunaan Lajur Pendekat

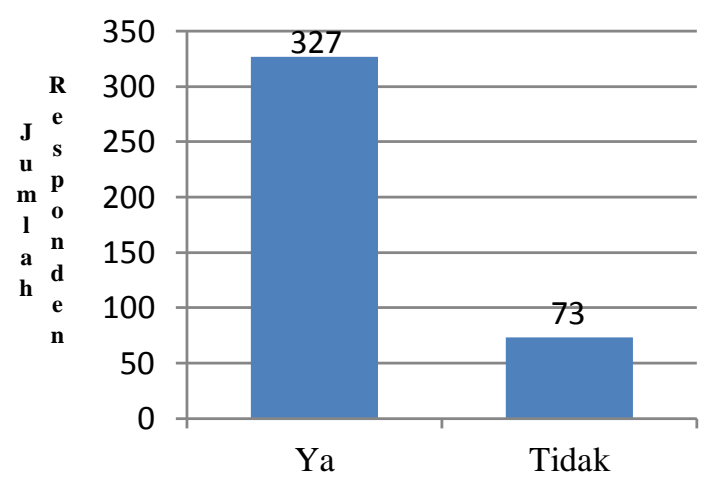

Gambar 15. Penggunaan Ruang Henti Khusus Sepeda Motor

Hasil Analisa Persepsi Pengendara Sepeda Motor tentang penyediaan Ruang Henti Khusus dengan Metode Logistic Regression

Analisa Logistic Regression ini digunakan untuk mengetahui persepsi penyediaan Ruang Henti Khusus oleh pengendara sepeda. Maka pemodelan yang dapat digunakan adalah :

- Model membutuhkan lajur pendekat :

$$
P_{i}=\frac{1}{1+e^{-(3,158-0,177 \cdot X 2-0,547 \cdot X 6)}}
$$

- Model membutuhkan Ruang Henti Khusus :

$P_{i}=\frac{1}{1+e^{-(0,439-0,123 \cdot X 2+0,202 \cdot X 4)}}$ 
Dimana :

$\mathrm{P}_{\mathrm{i}} \quad=$ Probabilitas membutuhkan Ruang

Henti Khusus

e = Bilangan alam $(2,718)$

$\mathrm{X}_{2}=$ Variabel bebas Usia

$\mathrm{X}_{4}=$ Variabel bebas Penghasilan

$\mathrm{X}_{6}=$ Variabel bebas Kepemilikan

Sepeda

$\beta_{0}=$ Konstanta

$\beta \mathrm{i} \quad=$ Koefisien untuk masing-masing variabel

Hasil Analisa Penentuan Lokasi dan alternatif Prioritas Penyediaan Ruang Henti Khusus dengan menggunakan Metode Analytic Hierarchy Process (AHP)

Analisa AHP ini digunakan untuk mengetahui alternatif penyediaan Ruang Henti Khusus yang sesuai pada tiap persimpangan pada lokasi studi. Lokasi persimpangan sebagai berikut:

- Jalan Galunggung - Jalan Tidar - Jalan Bondowoso
- Jalan Urip Sumoharjo - Jalan Panglima Sudirman - Jalan Pattimura

- Jalan Jaksa Agung Soeprapto - Jalan WR. Soepratman - Jalan Kaliurang

- Jalan LA. Soecipto - Jalan Soenandar Priyo S - Jalan Panji Suroso

Kriteria yang digunakan dalam menentukan alternatif penyediaan Ruang henti Khusus pada penelitian ini yaitu :

- Aspek Keselamatan

- Aspek Kenyamanan

- Aspek Waktu Tempuh

- Aspek Biaya Pembangunan

- Aspek Sosial Ekonomi

- Aspek Teknis

- Aspek Konservasi Lingkungan

Hasil analisa pemilihan kriteria dalam penyediaan Ruang Henti Khusus di Kota Malang yaitu sebagai berikut :

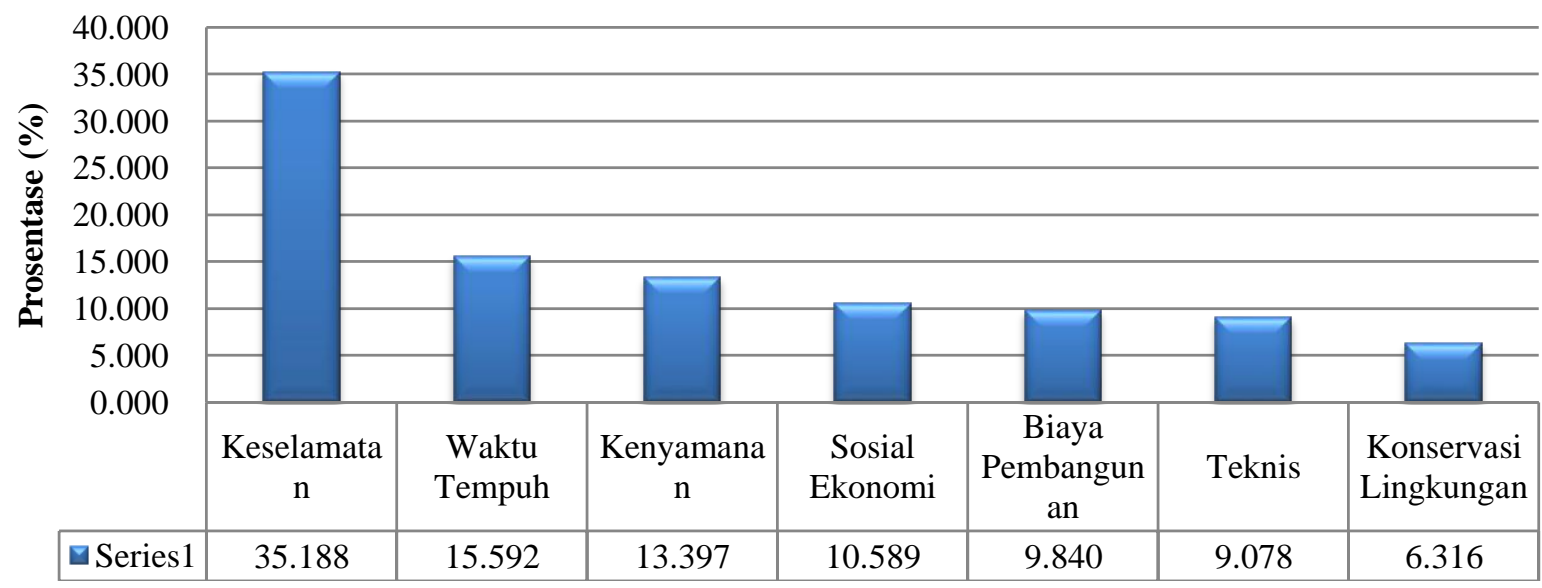

Gambar 16. Bobot Masing Masing Kriteria dalam Penyediaan Ruang Henti Khusus Sepeda Motor di Kota Malang

Alternatif penyediaan Ruang Henti Khusus di Kota Malang yaitu :

- Alternatif I: Perlu adanya Ruang Henti Khusus

- Alternatif II : Tidak Perlu Ruang Henti Khusus

Hasil analisa alternatif penyediaan Ruang Henti Khusus di Kota Malang yaitu sebagai berikut :

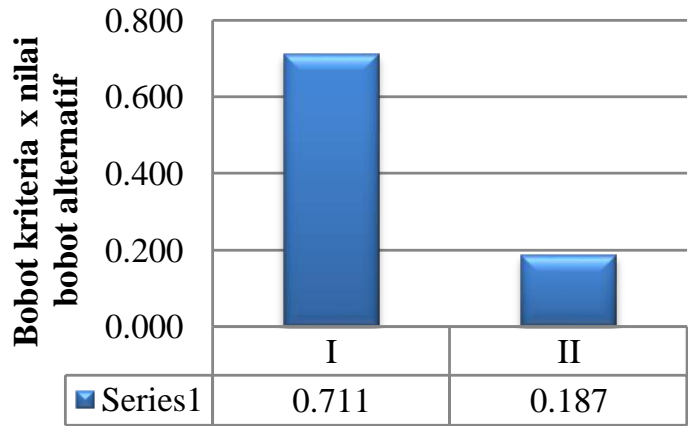

Gambar 17. Prioritas Alternatif Penyediaan Ruang Henti Khusus Sepeda Motor 
Hasil alternatif dari empat lokasi persimpangan di Kota Malang yang berpotensi dalam penyediaan Ruang Henti Khusus Sepeda Motor :

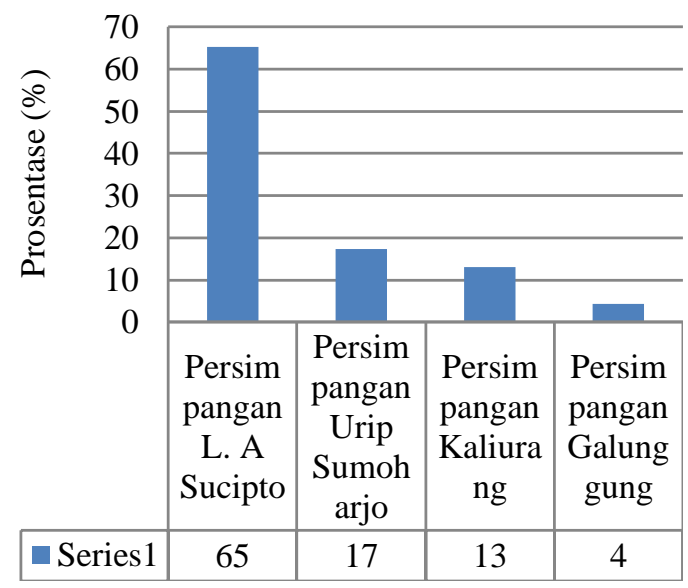

Gambar 18. Prioritas Alternatif Lokasi

Penyediaan Ruang Henti Khusus Sepeda Motor di Kota Malang

\section{KESIMPULAN DAN SARAN Kesimpulan}

Dari analisis yang telah dilakukan, diperoleh hasil sebagai berikut :

- Karakteristik pengendara sepeda motor di Kota Malang

- Karakteristik sosial ekonomi pengendara sepeda motor

Kelompok tertinggi pengendara sepeda motor di Kota Malang adalah berjenis kelamin laki-laki (64\%), usia 18-22 tahun (27\%), pendidikan SMA/MA (57\%), penghasilan < Rp 1.000 .000 (33\%), pekerjaan swasta (43\%), kepemilikan sepeda milik sendiri $(86 \%)$, dan jumlah sepeda motor $1(57 \%)$.

- Karakteristik perjalanan pengendara sepeda motor

Kelompok tertinggi pengendara sepeda motor di Kota Malang adalah berasal dari rumah $(79 \%)$, maksud perjalanan bekerja $(51 \%)$, tujuan lokasi kerja (51\%), jarak tempuh 5 $\mathrm{km}-10 \mathrm{~km}(25 \%)$, rutinitas kegiatan $6 \mathrm{kali} /$ minggu (45\%), dan waktu tempuh $20-30$ menit (35\%).

- Persepsi penyediaan Ruang Henti Khusus dari Stakeholder

- Bobot masing-masing kriteria yang akan digunakan dalam menentukan alternatif penyediaan Ruang Henti Khusus dan diperoleh dari hasil analisis Metode Analytic Hierarchy Process (AHP) adalah kriteria aspek keselamatan $(35,188 \%)$, aspek waktu tempuh $(15,592 \%), \quad$ aspek kenyamanan $(13,397 \%)$, aspek sosial ekonomi (10,589\%), aspek biaya pembangunan $(9,840 \%)$, aspek teknis $(9,078 \%)$, dan aspek konservasi lingkungan $(6,316 \%)$.

- Alternatif yang menjadi prioritas dalam penyediaan Ruang Henti Khusus di Kota Malang adalah Alternatif I, yaitu perlu adanya Ruang Henti Khusus.

- Ruas jalan di Kota Malang yang menjadi prioritas dalam penyediaan Ruang Henti Khusus adalah persimpangan Jalan LA. Soecipto Jalan Soenandar Priyo S - Jalan Panji Suroso.

\section{Saran}

- Penelitian dapat dikembangkan untuk memprediksi jumlah pengendara sepeda motor terkait penyediaan Ruang Henti Khusus untuk perencanaan di masa yang akan datang atau dikembangkan dengan memperhatikan aspek daya guna Ruang Henti Khusus yang terkait dengan kenyamanan atau kemudahan pengendara sepeda motor dalam bermanuver, misalnya dengan mempertimbangkan ukuran lajur pada saat sepeda motor membawa barang yang berlebihan.

- Hasil akhir penelitian dengan menggunakan Metode Analytic Hierarchy Process (AHP) sangat tergantung pada ketelitian pemilihan responden sebagai sampel penelitian sesuai dengan tujuan yang hendak dicapai. Selain itu tergantung pula pada kompetensi dan tingkat pemahaman yang tinggi dari masing-masing responden sehingga ketelitian dalam menentukan responden sangat berpengaruh.

- Perlu diadakan uji coba untuk mengimplementasikan desain Ruang Henti Khusus dengan menggunakan permukaan berwarna serta evaluasi tingkat efektivitasnya. Berdasarkan pengalaman dari berbagai Negara di 
dalam menerapkan RHK, merekomendasikan untuk menggunakan permukaan RHK berwarna. Dengan menggunakan permukaan berwarna pada RHK diperkirakan dapat memberikan pengaruh kepada pengguna jalan untuk mampu mengurangi kecepatan ketika akan memasuki RHK.

\section{DAFTAR PUSTAKA}

Bagulay, CJ. 1984. The British Traffic Conflict Studies. Proceedings of the NATO Advanced Research Workshop on International Calibration Study of Traffic Conflict Techniques. Copenhagen, May 25-27, 1987.

Chu Cong Minh, Kazushi Sano, \& Shoji Matsumoto. 2005. Characteristics of Passing and Paired Riding Maneuvres of Motorcycle. Paper on Journal of The Eastern Asia Society for Transport Studies, vol 6 pp 186 - 197, 2005.

Kusumaningsih, Dian. 2009. Studi Karakteristik Pengguna Sepeda dan Pra Design Lajur Sepeda di Wilayah Timur Kota Malang. Tesis. Tidak dipublikasikan. Malang : Universitas Brawijaya.

Hasan, Iqbal. 2002. Pokok Materi Metodologi Penelitian Dan aplikasinya. Jakarta: Ghalia Indonesia

Hermawanto, Tonny. 2006. Pemilihan Trase Jalan Dengan Metode IPA (Importance Performance Analysis) dan AHP (Analytic Hierarchy Process) (Studi Kasus Jalan Lingkar Utara Kota Blitar)”. Tesis. Tidak dipublikasikan. Malang : Universitas Brawijaya.

Idris, Muhammad. 2007. Pengaruh Ruang Henti Khusus Sepeda Motor Terhadap Konflik Lalu Lintas Pada Satu Persimpangan Bersinyal di Bandung. Tesis. Tidak dipublikasikan. Bandung : Institut Teknologi Bandung. 